\title{
A REVIEW OF COFFEE VARIETIES, VALUE CHAIN AND GROWINGREGIONS IN KENYA
}

\author{
Innocent Osoro Ngare, \\ School of Environmental Studies, Kenyatta University, \\ P.O Box 43844 - 00100, Nairobi
}

\begin{abstract}
Kenyan coffee is ranked among the best in the world and $99 \%$ is exported mainly to Germany, Sweden and Belgium, the USA and Saudi Arabia. Kenya produces quality Arabica beans which are generally recognized and upgraded with other relatively lower brands. In 1937, the Kenya Planters Cooperative Union (KPCU) was formed to represent small farmers' interests. In 1944, in the Coffee Board of Kenya (CBA) the law required smallholders to join local growing cooperatives run by government to reduce the power of large estates to control the board. Many reforms in the coffee industry have been initiated. This review explores evolution and existing coffee varieties in Kenya, the coffee value chain and the regions that grow coffee in Kenya. Additionally, the variety agronomics and appearance that encompass; quality potential at different altitudes, yield potential and nematodes susceptibility.
\end{abstract}

Key Words: Coffee varieties; Value chain; Grown regions

Corresponding email*ngare.innocent@gmail.com 


\section{TABLE OF CONTENTS}

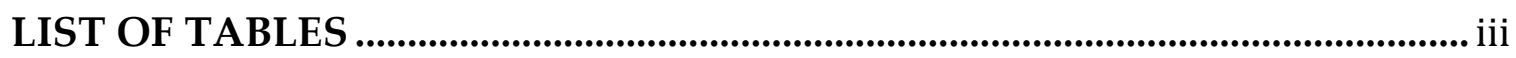

LIST OF FIGURES ....................................................................................................

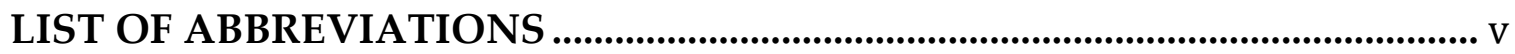

1.1 Background Information ............................................................................. 1

2.1 Coffee Varieties in Kenya ................................................................................. 1

2.1.1 SL28 Coffee variety ..................................................................................... 1

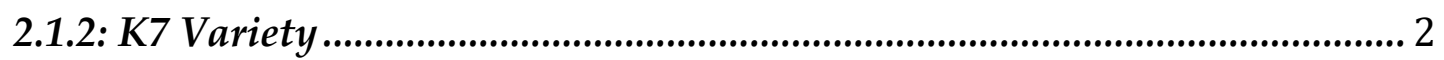

2.1.3 Batian variety ........................................................................................... 3

2.1.4 SL34 Variety ................................................................................................. 4

2.1.5 Ruiru 11 variety ............................................................................... 5

3.1 Coffee Value Chain in Kenya................................................................................. 7

4.1 Coffee growing regions in Kenya ....................................................................... 7

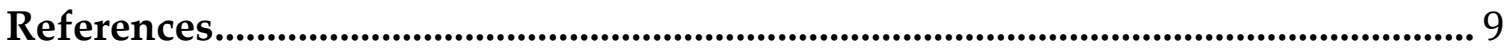




\section{LIST OF TABLES}

Table 1: SL28 variety agronomics.................................................................................. 2

Table 2: K7 variety agronomics ................................................................................... 3

Table 3: Batian variety agronomic.................................................................................. 4

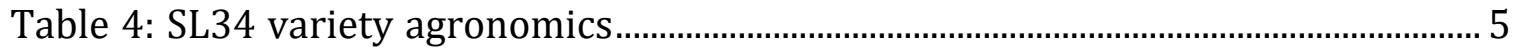

Table 5: Ruiru 11 variety agronomics.......................................................................... 6

Table 6: Coffee growing regions in Kenya …………………………………………..... 


\section{LIST OF FIGURES}

Figure 1(a), (b): SL28 habitus and dried beans ……………………………………..... 2

Figure 2 (a) Habitus appearance of K7 Variety................................................................. 3

Figure 3: Habitus for Batian variety ........................................................................... 4

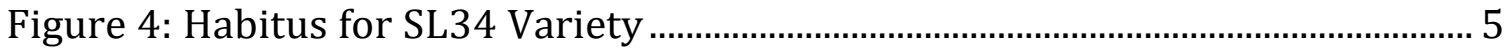

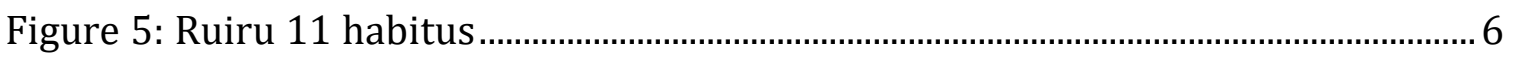

Figure 6: Coffee Value Chain ........................................................................................ 7 


\section{LIST OF ABBREVIATIONS}

CBA Coffee Board of Kenya

CVC Coffee Value Chain

KPCU Kenya Planters Cooperative Union

USA United States of America

CRF Coffee Research Foundation

WCR World Coffee Research

FAO Food Agricultural Organization 


\subsection{Background Information}

Kenyan coffee is ranked among the best in the world and 99\% is exported mainly to Germany, Sweden and Belgium, the USA and Saudi Arabia. Kenya produces quality Arabica beans which are generally recognized and upgraded with other relatively lower brands. In 1937, the Kenya Planters Cooperative Union (KPCU) was formed to represent small farmers' interests. In 1944, in the Coffee Board of Kenya (CBA) the law required smallholders to join local growing cooperatives run by government to reduce the power of large estates to control the board. Many reforms in the coffee industry have been initiated.

Under pressure from the World Bank, between 1990 and 2001 the government took a number of steps to lighten its control of the cluster. Such measures include: pulling out of cooperative management in 1991; putting an end to financial support for co-operatives in 1995; allowing farmers to choose among pulping, milling, and marketing agents for 1999; limiting the role of CBK as Reg. of the Coffee Board of Kenya; allowing farmers to choose among pulp and coffee factories; Restricting the role of the Kenyan Coffee Board (CBK) in 2001 as control board; privatize the coffee auction and allow a portion of coffee for the direct sale of exporters to bypass the auction; and expand the frequency of marketing licenses issued from 3 to 25 in 2006. To date, the KPCU is made up of 700,000 farmers, 300 cooperatives and 2,000 private properties (FAO, 2004).

\subsection{Coffee Varieties in Kenya}

Today, five famous coffee varieties dominate the Kenyan landscape; SL28, K7, Batian, SL34 and Ruiru 11 (Trabocca, 2020).

\subsubsection{SL28 Coffee variety}

SL28 is an Arabica Coffee sub- species that is a high yielding tall coffee tree and an absolutely outstanding cup profile. It is drought resistant, but still prone to leaf rust and berry disease attacks, although not to the degree of the French Mission Bourbon. SL28 is analogous to the genetic group Bourbon. SL28 is now the variety that really stood out from all the Scott's Laboratory varieties in Kenya. This is because, SL28 is primarily the most prosperous variety. This variety can be regenerated and start producing for extended periods, even decades. This implies that coffee industry still has a generational flow over the years. 
SL28 is one of Africa's most well-known and respected varieties. The latter has therefore spread over other parts of Africa (especially in Arabica-growing areas of Uganda) from Kenya, where it was initially selected in the 1930s, and now to Latin America. This variety is suitable for medium to high altitudes and is resistant to drought but susceptible to major coffee diseases. SL28 is distinguished by its rusticity, which means that it can remain untended for years or even decades and then revert back to better establishment. SL28 trees are between 60 to $80 \mathrm{yrs}$ old and still productive in many areas of Africa.

\section{Table 1: SL28 variety agronomics}

\begin{tabular}{|l|l|l|l|}
\hline Appearance & Signature & Leaf tip color & Bean size \\
\hline & Tall & Green & Large \\
\hline Agronomics & Optimal Altitude & $\begin{array}{l}\text { Quality potential at } \\
\text { high altitude }\end{array}$ & $\begin{array}{l}\text { Yield } \\
\text { Potential }\end{array}$ \\
\cline { 2 - 4 } & $\begin{array}{l}5^{\circ} \mathrm{N} \text { to } 5^{\circ} \mathrm{S}:>1200 \mathrm{~m} \\
5-15^{\circ} \mathrm{N} \text { and } 5-15^{\circ} \mathrm{S}: \\
>900 \mathrm{~m} \\
>15^{\circ} \mathrm{N} \text { and }>15^{\circ} \mathrm{S}: \\
>700 \mathrm{~m}\end{array}$ & Exceptional & Very High \\
\cline { 2 - 4 } & Coffee leaf rust & $\begin{array}{l}\text { Coffee berry } \\
\text { disease (CBD) }\end{array}$ & Nematodes \\
\cline { 2 - 4 } & Susceptible & Susceptible & Susceptible \\
\hline
\end{tabular}

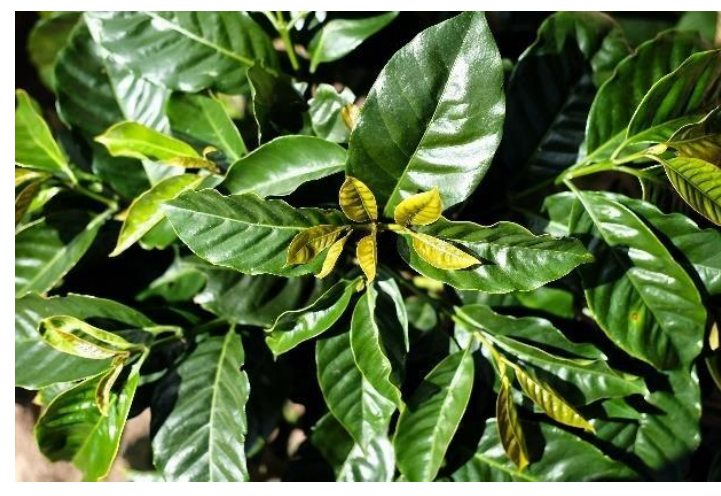

a

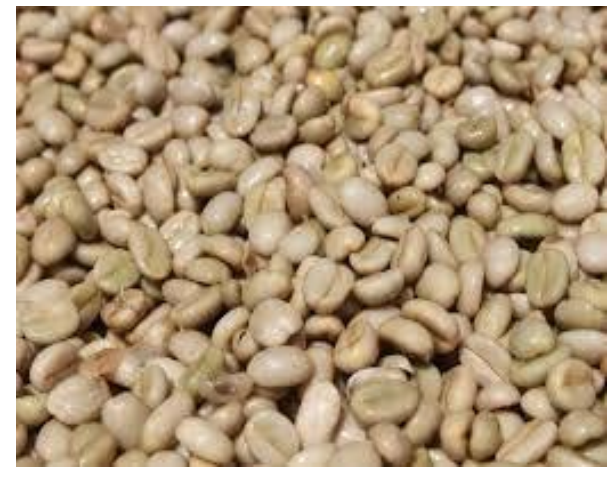

b

Figure 1(a), (b): SL28 habitus and dried beans.

\subsection{2: K7 Variety}

$\mathrm{K} 7$ is renowned for its rust and coffee bean disease resistance and has been broadly used in selective breeding schemes in Kenya. In 1936, after five generations of Scott 
Agricultural Laboratories selected from their native inhabitants, K7 was unveiled in Kenya.

Agronomically, K7 is typified by its scatter habits to young laterals, even though older primaries tend to decrease. It has distinctive medium to restrict leaves with young, light bronze spikes. It is suitable for lower elevations where coffee leaf rust is common (WCR,2021).

Table 2: K7 variety agronomics

\begin{tabular}{|l|l|l|l|}
\hline Appearance & Signature & Leaf tip color & Bean size \\
\hline & Tall & Light Bronze & Large \\
\hline Agronomics & Optimal Altitude & $\begin{array}{l}\text { Quality potential } \\
\text { at high altitude }\end{array}$ & Yield potential \\
\cline { 2 - 4 } & $\begin{array}{l}5^{\circ} \mathrm{N} \text { to } 5^{\circ} \mathrm{S}: 1000- \\
1600 \mathrm{~m} \text { Good }\end{array}$ & High \\
$\begin{array}{l}5-15^{\circ} \mathrm{N} \text { and 5- } \\
15^{\circ} \mathrm{S}: 700-1300 \mathrm{~m} \\
>15^{\circ} \mathrm{N} \text { and }>15^{\circ} \mathrm{S}: \\
400-1000 \mathrm{~m}\end{array}$ & \\
\cline { 2 - 5 } & Coffee leaf rust berry & $\begin{array}{l}\text { Coffee } \\
\text { disease (CBD) }\end{array}$ & \\
\cline { 2 - 5 } & Tolerant & Tolerant & Tolerant \\
\hline
\end{tabular}

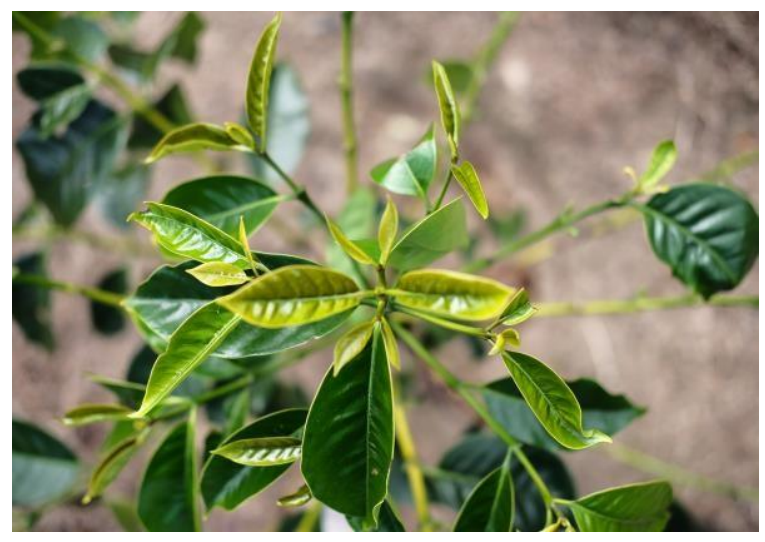

Figure 2 (a) Habitus appearance of K7 Variety

\subsubsection{Batian variety}

The Coffee Research Station (CRS), now the Coffee Research Institute (CRI), has been creating a variety immune to rust leaf and coffee berry disease, in Ruiru, Kenya. In 2010, Batian was released in Kenya. Based on Kenya's highest peak, Mount Kenya, Batian was developed to continue exhibiting resistance to coffee 
berry disease and leaf rust tolerance with an equivalent taste profile to SL 28 and 34. SL 28 and 34. The main distinction between Ruiru 11 and Batian is simply that Batian has been developed to have a usually better taste profile and still have the same or somewhat less disease resistance compared to Ruiru 11.Batian is a wide range with a very good cup profile and good production at high altitudes and good agricultural practices. Batian has a rapid maturation period and in 2 years does have its first year of production.

Table 3: Batian variety agronomic

\begin{tabular}{|c|c|c|c|}
\hline Appearance & Signature & Leaf tip color & Bean size \\
\hline & Tall & Green or Bronze & Very Large \\
\hline \multirow[t]{4}{*}{ Agronomics } & Optimal Altitude & $\begin{array}{l}\text { Quality potential } \\
\text { at high altitude }\end{array}$ & Yield potential \\
\hline & $\begin{array}{l}5^{\circ} \mathrm{N} \text { to } 5^{\circ} \mathrm{S}: \\
>1000 \mathrm{~m} \\
5-15^{\circ} \mathrm{N} \text { and } 5- \\
15^{\circ} \mathrm{S}:>700 \mathrm{~m} \\
>15^{\circ} \mathrm{N} \text { and }>15^{\circ} \mathrm{S}: \\
>400 \mathrm{~m}\end{array}$ & Very Good & High \\
\hline & Coffee leaf rust & $\begin{array}{l}\text { Coffee berry } \\
\text { disease (CBD) }\end{array}$ & Nematodes \\
\hline & Tolerant & Resistant & Susceptible \\
\hline
\end{tabular}

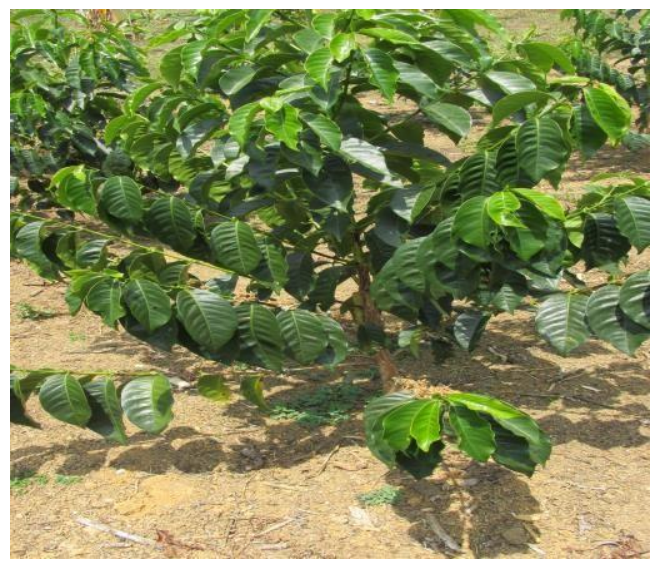

Figure 3: Habitus for Batian variety

\subsubsection{SL34 Variety}

SL34 was originally selected to Scott Agricultural Laboratories in Kenya in the late 1930s. Individual selection of the tree was made at the Scott Laboratories in Kenya 
during the period 1935-1939 and "SL." SL34 was chosen from the single tree on the Loresho estate in Kabete, the research was conducted in collaboration with the local owners of private estate in the Scott Laboratories. The tree has been labeled as the 'French mission.

SL34 is suitable for high altitude areas with good precipitation. It is characterized by dark bronze plants with a few green strains. The laterals are semi-erect, and tend to fall in the aged primary branches.

Table 4: SL34 variety agronomics

\begin{tabular}{|c|c|c|c|}
\hline Appearance & Signature & Leaf tip color & Bean size \\
\hline & Tall & Dark Bronze & Large \\
\hline \multirow[t]{4}{*}{ Agronomics } & Optimal Altitude & $\begin{array}{l}\text { Quality potential } \\
\text { at high altitude }\end{array}$ & Yield potential \\
\hline & $\begin{array}{l}5^{\circ} \mathrm{N} \text { to } 5^{\circ} \mathrm{S}: \\
>1200 \mathrm{~m} \\
5-15^{\circ} \mathrm{N} \text { and } 5- \\
15^{\circ} \mathrm{S}:>900 \mathrm{~m} \\
>15^{\circ} \mathrm{N} \text { and }>15^{\circ} \mathrm{S}: \\
>700 \mathrm{~m}\end{array}$ & Exceptional & High \\
\hline & Coffee leaf rust & $\begin{array}{l}\text { Coffee berry } \\
\text { disease (CBD) }\end{array}$ & Nematodes \\
\hline & Susceptible & Susceptible & Susceptible \\
\hline
\end{tabular}

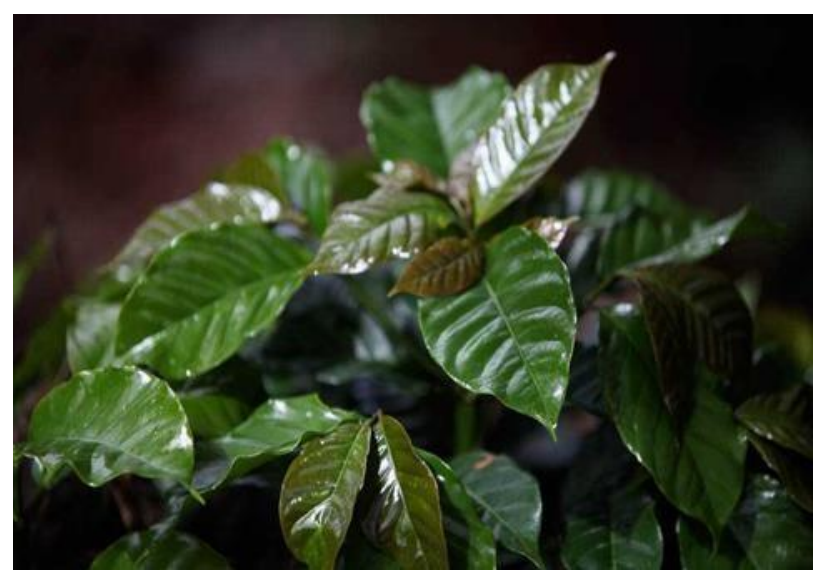

Figure 4: Habitus for SL34 Variety

\subsubsection{Ruiru 11 variety}

The Kenyan coffee sector was highly saturated by the SLs and did well until the outbreak of a coffee beer disease, which in 1967 plummeted almost half Kenya's 
production. This required the foundation for coffee research in Ruiru, Kenya to develop a range that could last such difficult times. They created a coined F1 hybrid, Ruiru 11 from the research Centre.

F1 hybrid is an evident interbreeding between two completely different parents that gives each parent a new offspring with a uniform combination of features. Therefore, it is safe to say that the variety Ruiru 11 is characterized by various existing varieties. Species such as SL28 abd SL34 have been retained for their good cup taste and species like Sudan Rume for resistance of coffee beer disease and the Catimor Variety have been added to add an extra coat to resist coffee berry disease and tolerance to leaf rust.

Table 5: Ruiru 11 variety agronomics

\begin{tabular}{|l|l|l|l|}
\hline Appearance & Signature & Leaf tip color & Bean size \\
\hline & Dwarf/Compact & Green or Bronze & Large \\
\hline Agronomics & Optimal Altitude & $\begin{array}{l}\text { Quality potential } \\
\text { at high altitude }\end{array}$ & Yield potential \\
\cline { 2 - 4 } & $\begin{array}{l}5^{\circ} \mathrm{N} \text { to } 5^{\circ} \mathrm{S}:>1000 \mathrm{~m} \\
5-15^{\circ} \mathrm{N} \text { and 5- } \\
15^{\circ} \mathrm{S}:>700 \mathrm{~m} \\
>15^{\circ} \mathrm{N} \text { and }>15^{\circ} \mathrm{S}:\end{array}$ & Good & Very High \\
$>400 \mathrm{~m}$ & & \\
\cline { 2 - 4 } & Coffee leaf rust & $\begin{array}{l}\text { Coffee berry } \\
\text { disease (CBD) }\end{array}$ & Nematodes \\
\cline { 2 - 4 } & Tolerant & Resistant & Susceptible \\
\hline
\end{tabular}

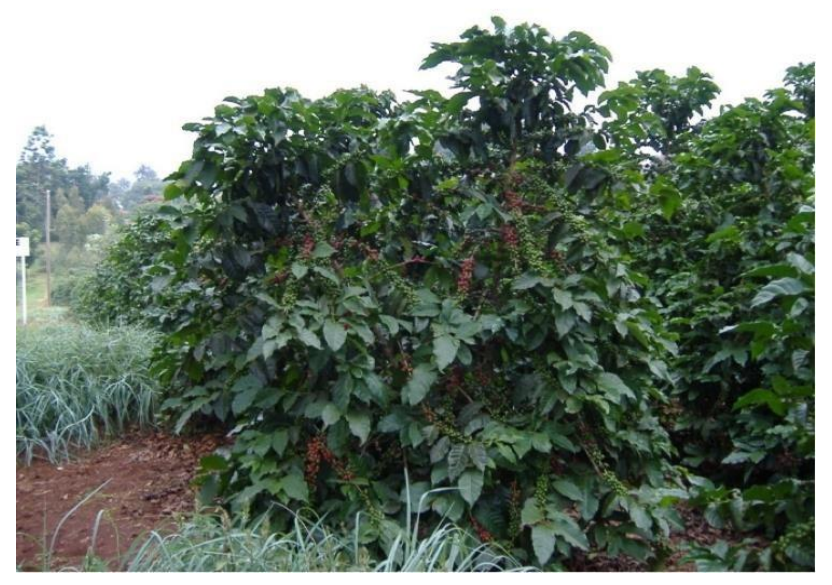

Figure 5: Ruiru 11 habitus 


\subsection{Coffee Value Chain in Kenya}

Growers are mainly involved in production, especially smallholders. Valueadding operations during production encompass soil preparation, fertilization, spraying, maintenance and harvesting. Maintenance and irrigation facilities are additional activities for large farms. At farm level, the Coffee Research Foundation (CRF) and private sector traders offer producers with complementary services and pertinent inputs. After harvesting the coffee cherries, they are ferried to the processing plants, dry or wet, and then to commercial millers for frying and grading. The cherries are removed from the fruit or pulp at the processing stage leaving the seed or bovine which is then dried. The method applies to the tastes of brushed and roasted coffee. Cherries are selected by hand in Kenya by selecting the ripe cherries. This process is labor intensive and expensive in Kenya.

Below is the schematic Coffee Value Chain (CVC) in Kenya (Fig. 6)

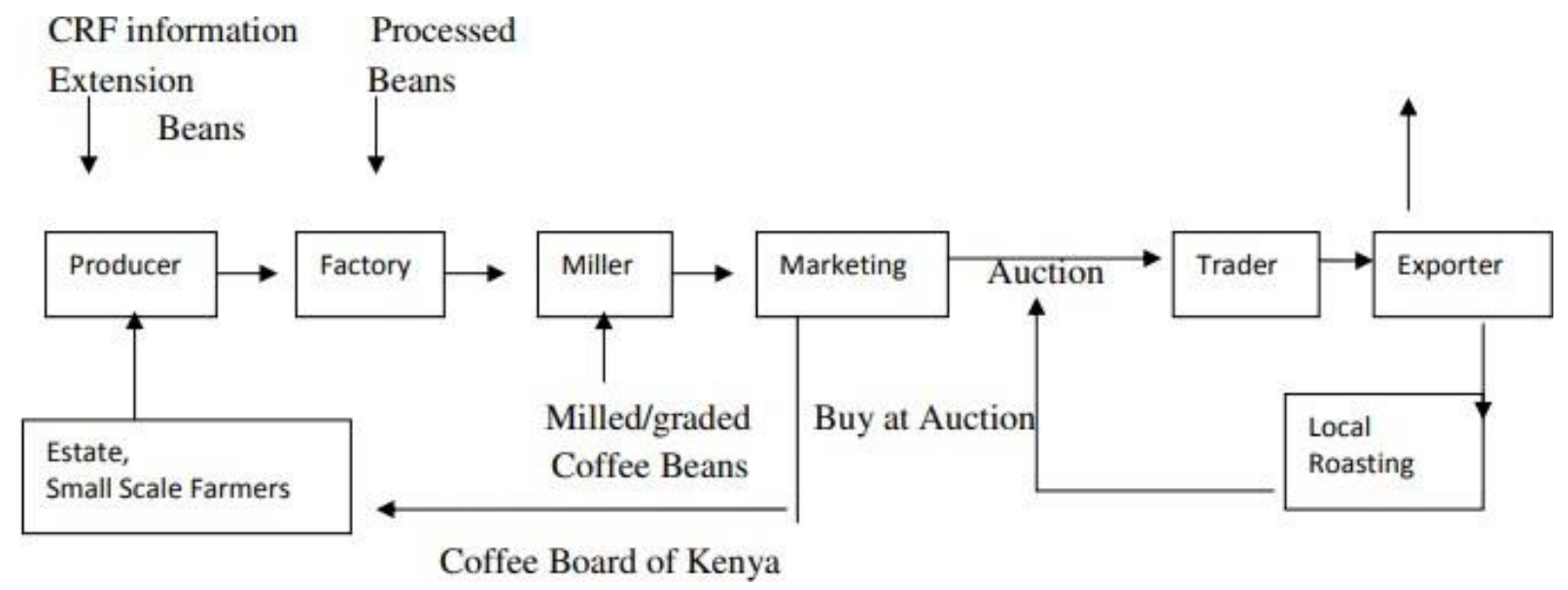

Figure 6: Coffee Value Chain

\subsection{Coffee growing regions in Kenya}

Coffee varieties are grown in different regions in Kenya that comprise of Arabica and Robusta species. Coffee in Kenya was first cultivated at St Austin's near Nairobi by Roman Catholic Fathers in 1889. It has since become really popular and developed a major export product in Kenya over the years. The cultivated species are Arabica and Robusta. The Arabica is a very good, mild coffee that is favored for mixing. The two coffee species are mainly cultivated by small farmers in the following areas; 
Table 6: Coffee growing regions in Kenya

\begin{tabular}{|c|l|}
\hline Region & Areas grown \\
\hline 1. Central region & $\begin{array}{l}\text { Kiambu, Nyeri, Kirinyaga and } \\
\text { Murang'a Counties }\end{array}$ \\
\hline 2. Eastern region & $\begin{array}{l}\text { Meru Central, Embu, Machakos, } \\
\text { Tharaka-Nithi and Makueni Counties }\end{array}$ \\
\hline 3. Rift-Valley region & $\begin{array}{l}\text { Nakuru, Nandi, Kipkelion, Trans } \\
\text { Nzoia and Baringo }\end{array}$ \\
\hline 4. Western region & $\begin{array}{l}\text { Bungoma, Vihiga and Kakamega } \\
\text { Counties }\end{array}$ \\
\hline 5. Nyanza region & $\begin{array}{l}\text { Kisii, Nyamira, Migori and Kisumu } \\
\text { Counties }\end{array}$ \\
\hline
\end{tabular}




\section{References}

FAO. (2004). The State of Agricultural Commodity Markets. FAO, Rome

Trabocca. (2020). Kenyan Coffee Varieties: A comprehensive review of Kenya coffee varieties.https://www.trabocca.com/our-stories/kenyan-coffeevarieties-a-comprehensive-overview-of-the-top-varieties . Retrieved 30 January, 2021

Kenya Co-operative Coffee Exporters Limited (KCCE) (2020). Coffee Growing Regions in Kenya. https://www.kencaffee.coop/coffee-growing-regionsin-kenya. Retrieved 30 January 2021.

World Coffee Research (WCR) (2021). Arabica Coffee varieties and research. https://varieties.worldcoffeeresearch.org. Retrieved 30 January 2021 